\title{
Seleção de genótipos de eucalipto resistentes à ferrugem (Puccinia psidii) através de parâmetros monocíclicos
}

\author{
Karina Carnielli Zamprogno Ferreira ${ }^{1}$; Celso Luis Marino²; Edson Luiz Furtado ${ }^{3}$
}

\author{
${ }^{1,3}$ Faculdade de Ciências Agronômicas de Botucatu (UNESP/Botucatu), Caixa Postal 237, 18.603-970, Botucatu, SP, Brazil. ${ }^{2}$ Instituto de Biociências/ \\ UNESP
}

Autor para correspondência:Karina Carnielli Zamprogno Ferreira (aline.miranda@ipef.br)

Data de chegada: 03/12/2014. Aceito para publicação em: 22/01/2015.

$10.1590 / 0100-5405 / 2062$

\section{RESUMO}

Ferreira, K.C.Z.; Marino, C.L.; Furtado, E.L. Seleção de genótipos de eucalipto resistentes à ferrugem (Puccinia psidii) através de parâmetros monocíclicos. Summa Phytopathologica, v.43, n.2, p.103-110, 2017.

A variabilidade genética dentro do gênero Eucalyptus para resistência à doenças e a fatores abióticos estão presentes, particularmente, com a ferrugem do eucalipto (Puccinia psidii WINTER), cuja primeira medida de controle é evitar o plantio comercial de materiais suscetíveis. A busca de caracteres quantitativos da resistência pode levar a genótipos superiores com resistência mais durável. Por isso, este estudo objetivou identificar parâmetros monocíclicos de avaliação da ferrugem em eucalipto, mais proximamente relacionados à resistência genética e estabelecer um ranking com os genótipos de maior resistência à ferrugem para compor um programa de melhoramento genético, além de relacionar a resposta do hospedeiro às vias metabólicas de defesa. Para tanto, foi realizado um estudo comparativo entre a avaliação da ferrugem no campo, com auxilio de escala qualitativa de severidade da doença com parâmetros monocíclicos quantitativos da doença em ambiente controlado. $\mathrm{O}$ predomínio de indivíduos suscetíveis indicou possíveis distorções de segregação nos cruzamentos, corroborando com hipóteses de estudos anteriores. Os resultados demonstraram, que o gene de resistência presente nesta população é dependente da ação de outros genes indiretamente relacionados à resistência e que participam das vias metabólicas de defesa das plantas.

Palavras-chave: Eucalyptus, Puccinia psidii, Herdabilidade, Correlação fenotípica, Período latente, Período infeccioso

\section{ABSTRACT}

Ferreira, K.C.Z.; Marino, C.L.; Furtado, E.L. Selection of Eucalyptus genotypes resistant to rust (Puccinia psidii) using monocyclic parameters Summa Phytopathologica, v.43, n.2, p.103-110, 2017.

Genetic variability within the genus Eucalyptus for resistance to diseases and abiotic factors is present, especially for eucalyptus rust (Puccinia psidii WINTER), the first control measure of which is to prevent commercial planting of susceptible plants. Search for quantitative resistance traits can lead to superior genotypes with durable resistance. This study aimed to identify monocyclic parameters for evaluating rust in eucalyptus, most closely related to genetic resistance, and to establish a ranking of genotypes with greater resistance to rust in order to prepare a breeding program, besides relating the host response to the plant defense pathways. Therefore, a comparative study was conducted between assessment of rust in the field, based on a qualitative disease severity scale, and quantitative monocyclic parameters of the disease in a controlled environment. Prevalence of susceptible individuals indicated possible segregation distortions, corroborating hypotheses of previous studies. Results showed that the resistance gene present in this population is dependent on the action of other genes that are indirectly related to resistance and that participate in the metabolic defense pathways of Eucalyptus.

Keywords: Eucalyptus, Puccinia psidii, heritability, phenotipic correlation, latent period, infective period

O sucesso da seleção de indivíduos, baseado apenas em valores fenotípicos, depende do grau de correspondência entre esses e o valor genético. Já o valor da herdabilidade depende de todos os componentes da variância, qualquer alteração em um deles afetará o valor da proporção herdável que expressa à proporção da variação total que é atribuída ao efeito genético, já observado por Falconer, 1989 (9). É possível alcançar melhores resultados na seleção de uma característica de baixa herdabilidade selecionando-se indiretamente em outros caracteres, de maiores herdabilidades, mas que apresentam alta correlação com a característica de interesse. Neste caso, pode-se utilizar valores elevados de Período Latente (PL) e valores inferiores de Frequencia de Infecção (FI) como indicativo para seleção.

O eucalipto é uma das principais fontes de celulose no mundo. No ranking mundial, o Brasil é o sexto maior produtor de celulose e o décimo primeiro em produção de papel (3).
A variabilidade genética do gênero Eucalyptus para resistência às doenças e a fatores fisiológicos adversos é muito grande e isto acontece, particularmente, com a ferrugem do eucalipto (Puccinia psidii WINTER), onde a primeira medida de controle é evitar o plantio comercial de materiais altamente suscetíveis. A variabilidade com relação à resistência a ferrugem também existe dentro de determinada procedência que pode ser detectada no campo, somente em condições de intenso ataque ou por meio de inoculações artificiais com alta concentração de esporos $(11 ; 1 ; 15)$.

Diversos estudos têm buscado contribuir para o entendimento da resistência do eucalipto à ferrugem $(10 ; 7 ; 19 ; 4 ; 17 ; 31 ; 29)$ mas no geral, estes estudos restringem-se à identificação e à seleção de espécies e procedências resistentes. Semelhante ao que ocorre em outras doenças, na ferrugem do eucalipto o mecanismo de resistência da planta é considerado como uma resistência parcial, geralmente condicionada 
por genes menores em que, embora o hospedeiro apresente reação de suscetibilidade, verifica-se uma baixa taxa de progresso da doença $(20 ; 6)$. Porém, para que a resistência parcial possa ser identificada e caracterizada em um grupo de genótipos, é necessário que entre estes haja variabilidade para os diversos componentes que a condicionam. Uma vez identificados os parâmetros ligados à resistência, é possível a seleção de genótipos através da mensuração de um único componente de resistência, desde que este apresente alta correlação com o progresso da doença e com os demais componentes da resistência $(22 ; 13)$.

Este procedimento poderá ser de grande utilidade para agilizar a seleção em programas de melhoramento genético de eucalipto onde a ferrugem represente fator limitante para o plantio.

Diante do exposto, os objetivos do presente trabalho foram: identificar os parâmetros monocíclicos relacionados à resistência genética à ferrugem em eucalipto em condições controladas e estabelecer um "ranking" de importância desses parâmetros para uso em programas de melhoramento florestal.

\section{MATERIAL E MÉTODOS}

Escolha da população com segregação para herança de resistência à ferrugem

Neste estudo, foi utilizada uma população proveniente do cruzamento controlado de híbridos interespecíficos (Eucalyptus grandis X E. urophylla), contrastantes na característica de resistência à ferrugem. O experimento foi instalado no final de 2005, no município de Santa Branca - SP, localizada Latitude: $23^{\circ} 39^{\prime} 75^{\prime}$ ' S, Longitude: $45^{\circ}$ 88' 57', cuja classificação do clima é Cfb segundo a Köppen e Geiger; $18.5^{\circ} \mathrm{C}$ é a temperatura média e a pluviosidade média anual de 1360 $\mathrm{mm}$. O delineamento utilizado foi de blocos casualisados e parcelas de 100 plantas, em 10 repetições, totalizando 1000 plantas F1. Como testemunhas foram utilizadas 100 plantas de cada clone parental, com espaçamento de $3,00 \times 2,00 \mathrm{~m}$.

As avaliações da ferrugem foram realizadas durante o primeiro semestre de 2006, com o auxilio da escala de severidade sugerida por Takahashi et al (2000) (28), e modificada por Zamprogno (2005) (32) (Figura 1).

Considerou-se as plantas classificadas qualitativamente nos níveis 0 e I da escala de severidade da doença como resistentes e aquelas classificadas no nível II e III como suscetíveis. Conforme escala diagramática utilizada (31): $0=$ corresponde a uma planta livre de sintomas ou planta sadia; $1=$ poucas pustulas nas folhas; $2=$ pustulas típicas porém esparsas nas folhas mais velhas e abundantes nas folhas e partes novas dos ramos; e $3=$ brotações com pustulas normais, abundantes nos limbos, pecíolos e folhas jovens, ramos com necrose apical e perda da dominância pela planta.

Escolha de indivíduos representativos da população para avaliação em ambiente controlado e inoculação

Para a avaliação em ambiente controlado, foram selecionadas 200 plantas no campo, sendo 50 representantes de cada nível da escala de severidade da doença. Os representantes de severidade nível 0 e I foram preferencialmente escolhidos aqueles rodeados de indivíduos mais suscetíveis (níveis de severidade II e III), da mesma forma, aqueles com nível de severidade II e III preferencialmente circundados por indivíduos nível 0 e I, eliminando as chances de ocorrência de resistência por escape à doença.

As plantas escolhidas foram marcadas e cortadas para a produção de brotos. Foi realizada uma amostragem de folhas dessas árvores para

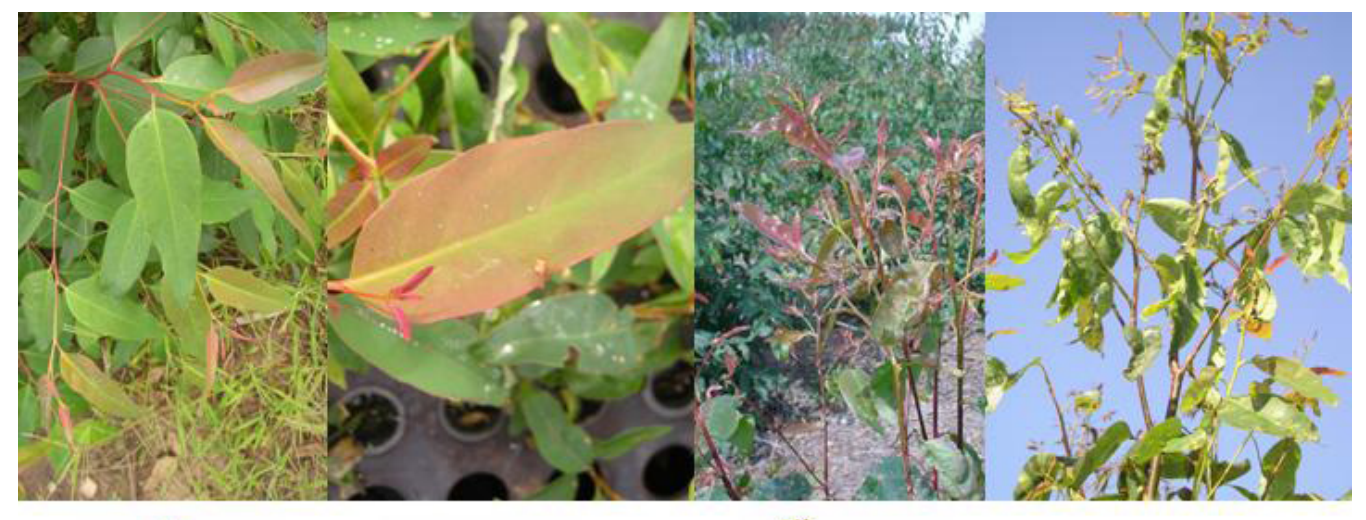

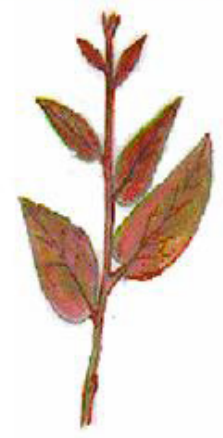

0

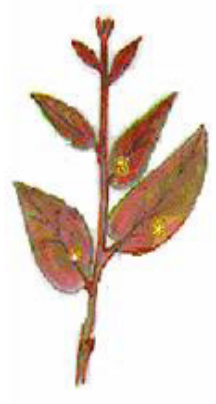

I

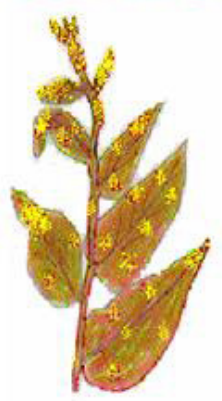

II

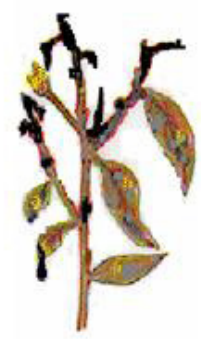

III

Figura 1. Escala de notas para avaliação da resistência à ferrugem do eucalipto no campo onde: $\mathbf{0}=$ ausência de esporulação ou planta sadia; $\mathbf{I}=$ pústulas puntiformes isoladas nos limbos e folhas novas; II = esporulação mais abundante nos limbos e folhas novas; III = esporulação intensa em ambas as faces das folhas, podendo ocorrer em pecíolos e hastes jovens. (Takahashi et al, (2000), modificada por Zamprogno \& Furtado (20085). 
“fingerprint" das mesmas após a clonagem.

As plantas foram clonadas através de mini estaquia, obtendo-se, pelo menos dez repetições de cada planta. As mudas em tubetes foram colocadas em bandejas, dentro de uma câmara no Departamento de Proteção Vegetal da Faculdade de Ciências Agronômicas - UNESP, Botucatu, onde a temperatura, luz e a umidade foram controladas. A câmara foi previamente colocada para nebulizar, e o ambiente mantido saturado no período de 24 horas. Após a inoculação, as mudas foram mantidas na câmara por 35 dias, em temperatura de $22^{\circ} \mathrm{C}$, fotoperíodo de 12 horas e umidade relativa em torno de $80 \%$.

Para a inoculação foram utilizados uredósporos de $P$. psidii retirados de folhas de eucalipto infectadas com esporos coletados no campo experimental (local de infecção natural de ferrugem) e mantidos em plantas suscetíveis para a multiplicação do inóculo. Os espóros foram desprendidos das folhas com auxílio de um estilete e suspensos em água destilada acrescida de Tween $80 \%$. A concentração da suspensão de espóros foi ajustada para 100.000 esporos $/ \mathrm{mL}$. A aplicação do inóculo nas mudas teve o auxilio de um atomizador, acionado por um compressor elétrico a $0,8 \mathrm{kgf} / \mathrm{cm}^{2}$ de pressão. Para garantir que todas as plantas receberam a suspensão de esporos, as mudas foram distribuídas ao acaso nas bandejas e toda bandeja possuía três testemunhas (clones do parental suscetível).

\section{Avaliação da ferrugem em ambiente controlado}

No total foram alocadas nas bandejas 45 mudas distribuídas inteiramente ao acaso. Cada bandeja continha também três testemunhas (parental suscetível), usadas para monitorar a eficácia da inoculação. No dia seguinte à inoculação, iniciou-se a avaliação individual das mudas, tendo esta, perdurado por 25 dias consecutivos.

Para a realização da estimativa dos parâmetros genéticos, foram utilizados os seguintes parâmetros:

Período de incubação (PI): tempo entre a inoculação e o aparecimento dos primeiros sintomas visíveis (20). Para a ferrugem do eucalipto, os primeiros sintomas visíveis de infecção constituem-se em pontos esbranquiçados e levemente salientes. Em caso de reação de hipersensibilidade, os primeiros sintomas considerados foram às lesões necróticas observadas na superfície foliar.

Após a inoculação, as mudas de eucalipto foram avaliadas a cada 24 horas até que fossem constatados os primeiros sintomas. As avaliações foram realizadas nos dois pares de folhas primárias.

Período latente (PL): tempo entre a inoculação e a produção de esporos na lesão formada, também reconhecida por tempo de geração do patógeno (20). Consideraram-se as pústulas formadas por uredósporos (amarelas), que foram contadas cumulativamente a cada 24 horas, até que cessassem o aparecimento de novas pústulas. O período de latência considerado é o tempo decorrido entre a inoculação e a estabilização no aparecimento de novas pústulas (21).

Freqüência de infecção (FI): proporção de esporos inoculados que resultam em infecção (20). Foi considerado o número médio de pústulas esporulantes por folha primária, após a estabilização de seu aparecimento.

Intensidade de infecção (II): área foliar relativa ocupada pelas lesões, resultante do número de lesões por unidade de área foliar e de seu tamanho. Após a estabilização do aparecimento e crescimento de pústulas ou lesões necróticas, foi determinada a porcentagem relativa de área foliar ocupada pelos sinais produzidos pela infecção de Puccinia psidii. Considerou-se uma escala de $0 \%$ (sem sintomas) a $100 \%$ (máxima severidade de infecção), com base na porcentagem de área de lâmina foliar afetada.

Os quatro parâmetros avaliados em condições controladas (PI, PL,
FI e II), foram correlacionados com os valores do grau de infecção (GI) obtidos no ensaio de campo.

\section{Análise estatística}

Para o processamento dos dados foi utilizado o programa SELEGEN - Seleção Genética Computadorizada, desenvolvido pelo Centro Nacional de Pesquisa de Florestas da Embrapa - Empresa Brasileira de Pesquisa Agropecuária, que aplica técnicas de avaliação genética envolvendo simultaneamente a predição de valores genéticos e a estimação de componentes de variância. O procedimento adotado pelo aplicativo para predição de valores genéticos é o BLUP (melhor predição linear não viesada), utilizando estimativas de componentes de variância obtidas pelo método da máxima verossimilhança restrita (REML). O programa emprega os modelos, estimadores e preditores apresentados por Resende (2002) (25) e pode ser utilizado para plantas alógamas, autógamas e com sistema reprodutivo misto.

\section{RESULTADOS E DISCUSSÃO}

\section{Avaliação da ferrugem no campo}

No campo, foram avaliadas 1000 plantas, onde: 57 ou 6\% foram classificadas no nível 0 da escala de severidade, 372 ou $37 \%$ no nível I, 350 ou $35 \%$ no nível II e 194 ou 19\% no nível III. Também, foram contabilizadas 27 plantas mortas. A segregação fenotípica esperada segundo a literatura, para casos de doenças de caráter monogênico era de $1: 1$, já descrito inclusive para ferrugem no eucalipto $(17 ; 31 ; 29)$, sendo os níveis 0 e I considerados resistentes por apresentam poucas pústulas, e não causarem dano econômico na cultura. Por outro lado os indivíduos II e III considerados suscetíveis, por apresentarem abundante esporulação comprometendo o desenvolvimento natural da planta.

Na Tabela 1, são apresentados os resultados observados no experimento de campo e comparado com o resultado esperado de 1:1 quanto à resistência e suscetibilidade.

$\mathrm{O}$ teste de ajustamento indicou um desvio significativo entre os resultados observados e esperados não permitindo aceitar a hipótese de segregação de 1:1 no ensaio de campo. Resultados semelhantes foram observados em eucalipto por Alves, 2008 (2); Rosado, 2007 (26); Teixeira, 2009; Paterniani et al., (2002) (23), com Physopella zeae no milho e por Vieira et al., (2006) (31) com Puccinia graminis em trigo. Estes autores sugerem que o caráter resistência a ferrugem deva se tratar de uma interação gênica, que pode ser produzida pela atuação conjunta de dois ou mais pares de genes. No estudo de Alves, (2008) (2), foi observado o efeito epistático que pode ocorrer se a resistência à ferrugem depender de dois genes principais, onde, um codifica para a proteína "R" responsável pelo reconhecimento das proteínas "Avr" de Puccinia psidii de modo direto e outro, que codifica algum membro importante da cadeia de transdução de sinais, como por exemplo, uma proteína quinase (fatores ligados as vias metabólicas de defesa vegetal). A falta da molécula sinalizadora bloquearia a ativação dos mecanismos de resistência da mesma forma que a falta da proteína

Tabela 1. Teste Qui-quadrado para segregação da ferrugem no campo

\begin{tabular}{lcccc}
\hline Fenótipo & $\begin{array}{c}\text { Resultados } \\
\text { Observados }\end{array}$ & $\begin{array}{c}\text { Resultados } \\
\text { Esperados (1:1) }\end{array}$ & $\mathbf{D}=\mathbf{O}$ - E & $\mathbf{D}^{\mathbf{2}}$ / E \\
\hline Resistente & 429 & 486,5 & $-57,5$ & 6,7960 \\
Suscetível & 544 & 486,5 & 57,5 & 6,7960 \\
Total & 973 & 973 & 0 & 13,5920 \\
\hline
\end{tabular}


"R" resultaria em suscetibilidade, o que caracteriza as alterações nos padrões de segregação esperados. Junghans et al, (2003) (17), sugere que a resistência está ligada a uma associação do gene de efeito principal em combinação favorável com genes de menor efeito. Indivíduos que não possuam os alelos favoráveis poderão apresentar suscetibilidade a doença.

Para validação das hipóteses acima mencionada, faz-se necessário um estudo mais aprofundado da herança da resistência a doença, incluindo a análise da segregação da autofecundação dos genitores. Os resultados obtidos neste estudo não permitem inferir sobre o controle genético a Puccinia psidii, contudo, é possível verificar ao avaliar o grau das lesões causadas pela doença, a ocorrência de uma distribuição contínua do caráter. Vale ressaltar que o uso da escala de severidade da doença na classificação de indivíduos nos programas de melhoramento genético de eucalipto tem contribuído muito para seleção contínua de alelos favoráveis a resistência, uma vez que é dada preferência na seleção de árvores classificadas nos níveis 0 e I da escala de severidade.

\section{Avaliação da ferrugem em ambiente controlado \\ Período de Incubação}

O período de incubação (PI) por ser um parâmetro que avalia o tempo entre a inoculação e o aparecimento dos primeiros sintomas visíveis, é um fator que indica o sucesso da infecção. Este parâmetro está muito mais associado aos mecanismos de infecção do patógeno e seus genes de virulência além dos fatores ambientais, que aos genes de resistência propriamente ditos da planta. Isso porque, nesse período, os mecanismos de defesa atuantes são os chamados "pré formados", que promovem uma espécie de barreira física contra a penetração do patógeno. Assim, folhas com maior número de tricomas, camada cerosa mais espessa, níveis de óleos essenciais mais elevados, estômatos menores ou arquitetura foliar mais inclinada (que impede a formação de camada superficial de água sobre o tecido), são beneficiadas e apresentarão um período de incubação mais longo.

O PI observado foi medido no intervalo de 1 à 15 dias, ou seja, indivíduos com poucos mecanismos de resistência pré formados apresentaram sintomas nas primeiras 72 horas. $\mathrm{O}$ que demonstra que nesta fase a atuação de genes de resistência bioquímica, ainda não ocorre são os valores observados de PI que podem ser longos até mesmo em clones que apresentarão no decorrer das avaliações um alto nível de severidade da doença. Na Tabela 2, são apresentados os valores médios dos quatro parâmetros monocíclicos avaliados para cada indivíduo.

\section{Período de Latência}

O período de latência (PL) foi o parâmetro que avaliou o tempo entre a inoculação e a produção de esporos ou o chamado "tempo de geração do patógeno". O período de latência tem início após o aparecimento das urédias "fleck" e segue até o décimo oitavo dia após a inoculação, considerado tempo hábil para o estabelecimento da doença em condições ideais. Este parâmetro está associado a capacidade da planta em reprimir o crescimento do patógeno (esporulação), ou impedir seu desenvolvimento por completo. Nesta fase pode haver atuação de mecanismos de defesa "pós-formados", como as PR-proteinas (18). De acordo com outros estudos, as variações no período latente médio da ferrugem ocorrem em razão da combinação genótipo do hospedeiro e genótipo do patógeno, das condições ambientais e da metodologia de avaliação $(5 ; 27 ; 17)$.

Neste estudo, foi observado que indivíduos classificados no campo nos níveis mais elevados de severidade possuem um período de latência menor que aqueles considerados mais resistentes na escala de severidade da doença no campo. Portanto, visualiza-se na Figura 2, que quanto maior o período de latência menor a severidade da doença.

\section{Freqüência de infecção}

A freqüência de infecção (FI) foi o parâmetro que avaliou o número médio de pústulas esporulantes por folha, do $22^{\circ}$ até o $28^{\circ}$ dia. Este parâmetro está muito relacionado as condições ambientais e a viabilidade dos espóros do fungo. No campo, algumas plantas podem não apresentar sintomas, devido a um efeito de "escape ambiental" onde o patógeno não encontra condições ideais de temperatura e umidade para se reproduzir. O fungo inicia seu ciclo a partir dos urediniósporos, que atingem uma brotação nova suscetível da planta (15), e a partir daí fica extremamente dependente das condições ambientais.

As plantas que não apresentaram esporulações até o $28^{\circ}$ dia foram consideradas altamente resistentes ou imunes.

\section{Intensidade de infeç̧ão}

A intensidade de infecção (II) foi o parâmetro que considerou a área foliar ocupada pelas lesões. Criou-se uma escala de $0 \%$ (sem sintomas) a $20 \%$ (máxima severidade de infecção observada), com base na porcentagem de área de lâmina foliar afetada, no par de folhas primárias, avaliadas do $29^{\circ}$ ao $35^{\circ}$ dia após a inoculação. A escala diagramática apresentada na figura 3 , foi utilizada na classificação das lesões que variaram de 0 à $20 \%$ do tecido foliar lesionado, considerando que a última avaliação foi realizada aos 35 dias após inoculação.

Este parâmetro avaliou as conseqüências no final das ações do patógeno, bem como, as reações do hospedeiro. Quanto maior a área lesionada, menor é a área fotossintética da planta e conseqüentemente sua produção será reduzida. No campo, plantas muito suscetíveis após 60 dias de infecção poderão apresentar brotos novos com 100\% do tecido lesionado e ponteira encarquilhadas e folhas primárias com até $50 \%$ de tecido lesionado, dependendo do nível de severidade da doença (28)

Classificação dos indivíduos resistentes à ferrugem para compor o Programa de Melhoramento Genético

Dos clones testados, 45 apresentaram resistência completa ao patógeno (Tabela 2)

O programa SELEGEN apresentou para cada variável analisada um valor médio que permitiu a classificação dos indivíduos, de acordo com os ganhos genéticos possíveis no caso de cruzamento dos mesmos. Os valores preditos na análise do SELEGEN demonstraram também, que quanto maiores PI e PL, maior a herdabilidade para resistência. Observa-se que os dois parâmetros se completam, ou seja, quando há elevação de PI ocorre elevação de PL também. Em contra partida, quanto menores FI e II, melhores serão os níveis de resistência do hospedeiro.

Ao unirmos todos os parâmetros em uma única fórmula somatória, a fim de selecionar os indivíduos mais promissores para resistência à ferrugem, utilizando os valores das médias das variáveis mensuradas, obtivemos o que chamamos de "Somatória para Resistência"

$$
\begin{aligned}
& \sum \mathrm{R}=(\mathrm{PI}+\mathrm{PL})-(\mathrm{FI}+\mathrm{II}) \\
& \text { Onde: } \\
& \sum \mathrm{R}=\text { Somatória da Resistência } \\
& \mathrm{PI}=\text { Período de Incubação (dias) } \\
& \mathrm{PL}=\text { Período de Latência (dias) } \\
& \mathrm{FI}=\text { Freqüência de Infecção ( }{ }^{\circ} \text { de esporos) } \\
& \mathrm{II}=\text { Índice de Infecção (\% área lesionada) } \\
& \text { Os valores médios considerados variam no caso de PI de } 1 \text { à } 7,
\end{aligned}
$$


Tabela 2. Média das variáveis avaliadas: PI (Período de Incubação em dias); PL (Período de Latência em dias); FI (Freqüência de Infecção em número médio de esporos por $\mathrm{cm}^{2}$ ); II (Índice de Infecção em \% de tecido lesionado) para cada indivíduo selecionado de 01 a 201

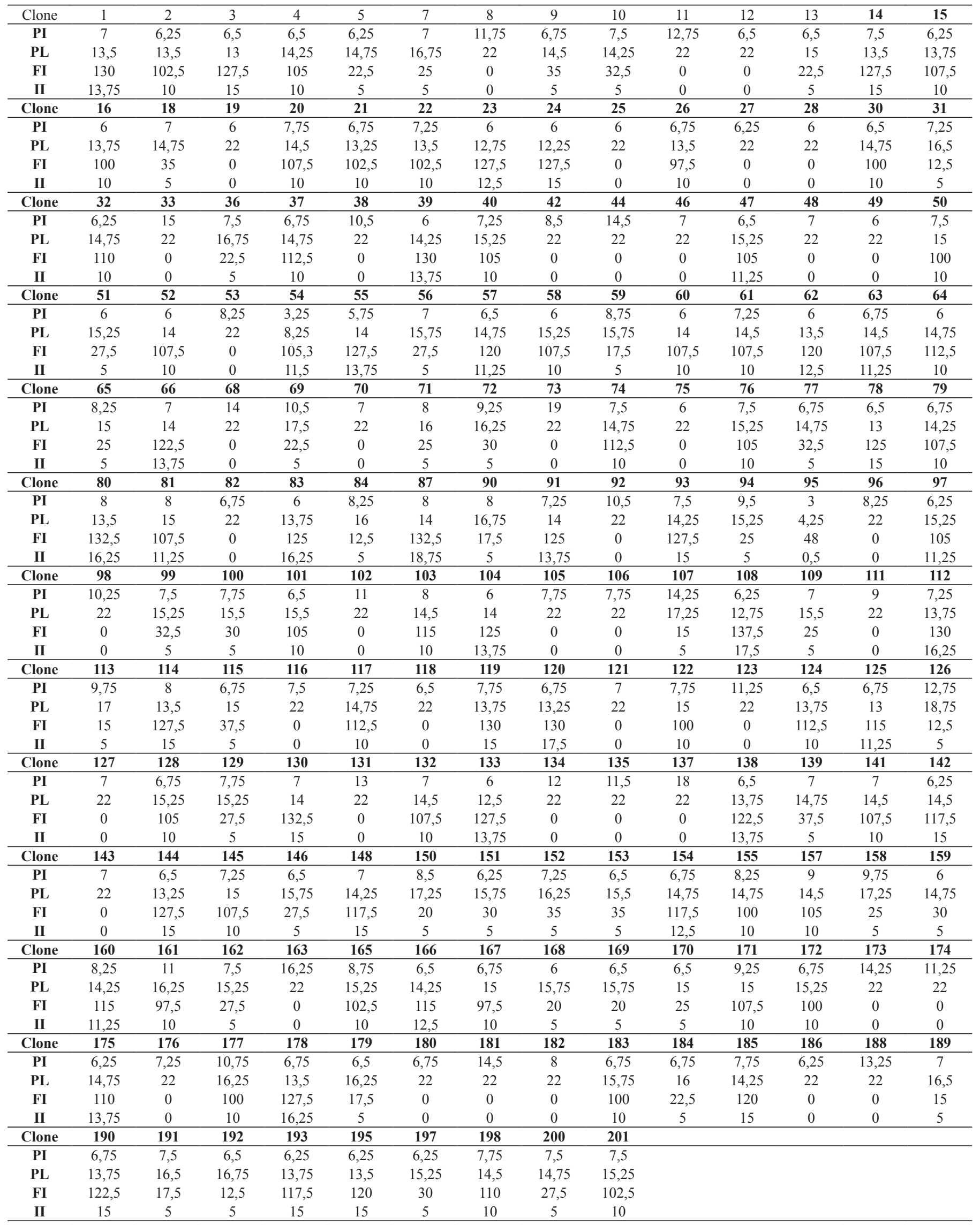




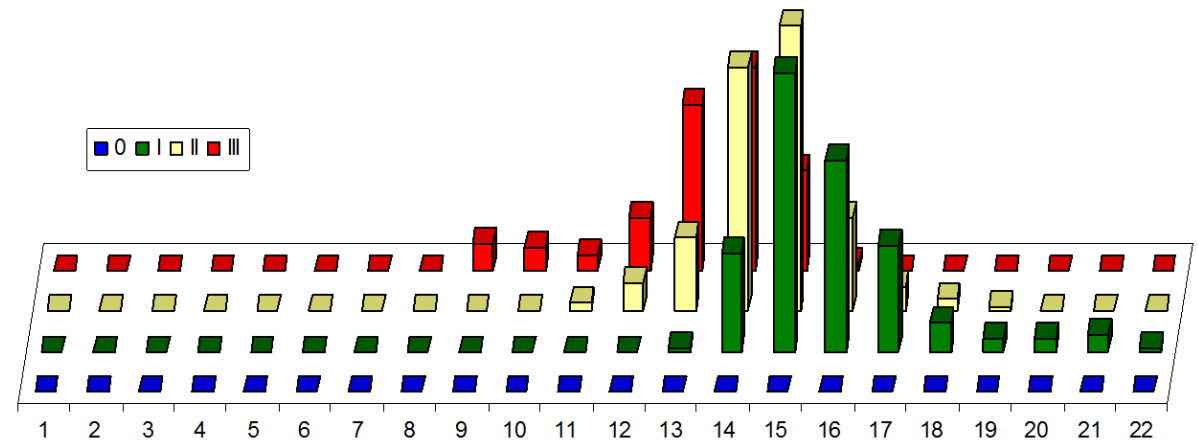

Dias após a inoculação

Figura 2. Gráfico do período de latência em relação aos níveis de severidade da doença avaliada na população em estudo:

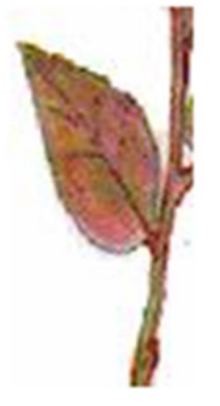

$0 \%$

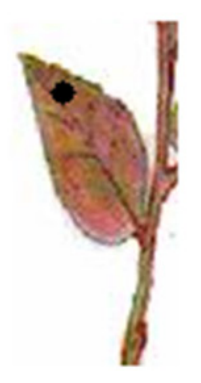

$5 \%$

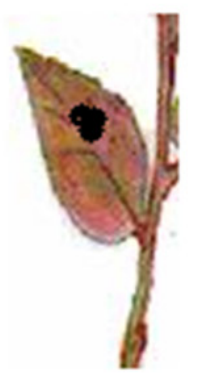

$10 \%$

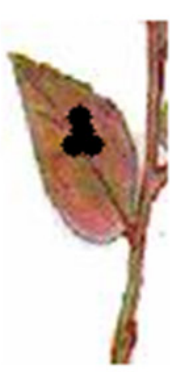

$15 \%$

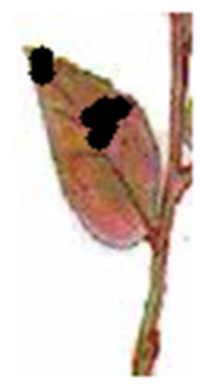

$20 \%$

Figura 3. Escala diagramática de lesões necróticas provocadas por Puccinia psidii em eucalipto aos 35 dias após inoculação.

Tabela 3. Análises de cada uma das variáveis componentes de resistência à ferrugem em eucalipto

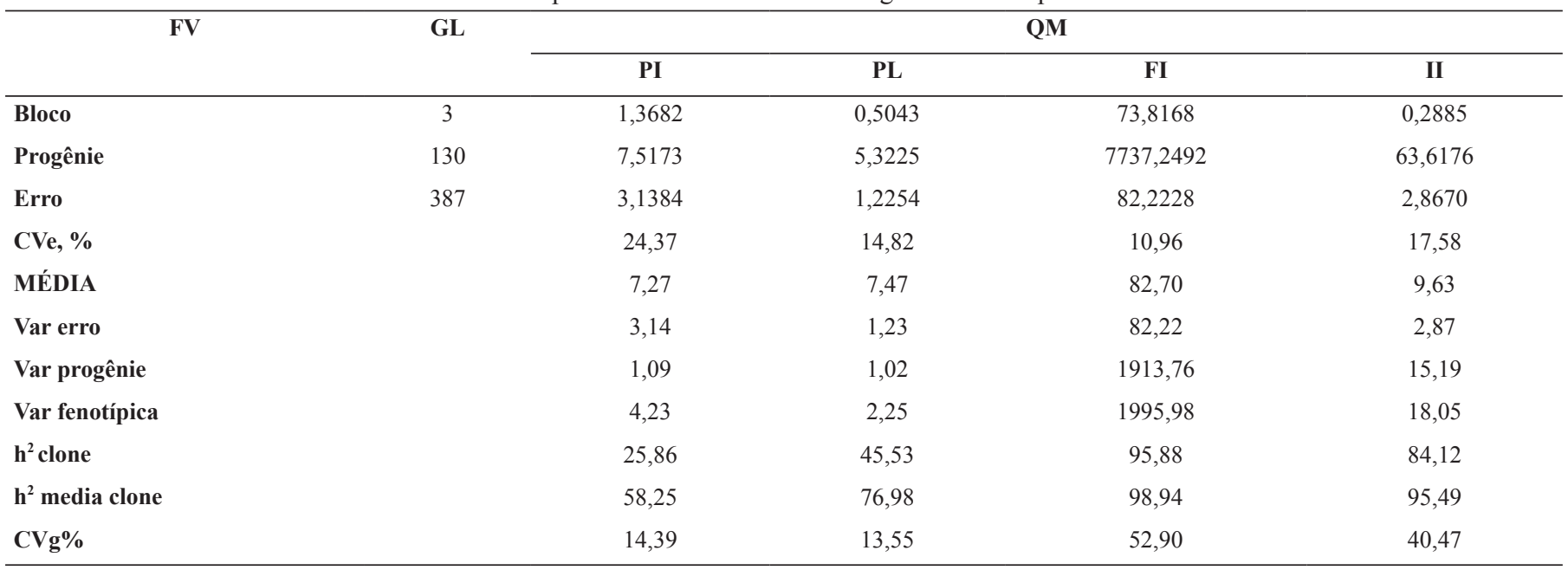

PL de 8 à 18, sendo o valor 22 atribuído apenas aos clones que não apresentaram nenhum sintoma, FI variando de 0 à 16 (número de esporos contabilizados durante a avaliação / 10) e II de 0 à 20.

Com a utilização da fórmula da somatória das variáveis foi possível classificar os indivíduos mais promissores para fazerem parte do programa de melhoramento genético da empresa e que apresentam a maior somatória de alelos responsáveis pela resistência. Estes estão representados na figura 4 com valores positivos.

Observou-se, também, que houve transição entre os níveis de severidade quando comparados com a avaliação de campo, porém, não houve nenhuma alteração qualitativa, ou seja, indivíduos classificados nos níveis 0 e I transitaram apenas entre estas classes, permanecendo resistentes. Da mesma forma, aqueles classificados nos níveis II e III, apesar da constatação de transição entre os níveis de severidade da 
Tabela 4. Coeficiente de correlação fenotípica entre os componentes de resistência à ferrugem em eucalipto

\begin{tabular}{cccccc}
\hline Variável & $\begin{array}{c}\text { PI } \\
\text { (dias) }\end{array}$ & $\begin{array}{c}\text { PL } \\
\text { (dias) }\end{array}$ & $\begin{array}{c}\text { FI } \\
\left(\mathbf{n}^{\mathbf{0}} \text { de esporos) }\right.\end{array}$ & $\begin{array}{c}\text { GI } \\
\text { (severidade) }\end{array}$ & $\begin{array}{c}\text { II } \\
\text { (\% de área foliar lesionada) }\end{array}$ \\
\hline PI (dias) & 1 & 0.5535 & -0.2150 & -0.1744 & -0.1662 \\
PL (PI+dias) & 0.5535 & 1 & -0.6171 & -0.5600 & -0.5679 \\
FI (n de esporos) & -0.2150 & -0.6171 & 1 & 0.9176 & 0.8935 \\
GI (nota) & -0.1744 & -0.5600 & 0.9176 & 1 & 0.9153 \\
II (\% de área foliar lesionada) & -0.1662 & -0.5679 & 0.8935 & 0.9153 & 1 \\
\hline
\end{tabular}

PI= Período de Incubação; PL=Período Latente; FI=Frequência de Infecção; GI=Grau de Intenção; II=Intensidade de Infecção

doença, permanecem qualitativamente classificados suscetíveis.

\section{Correlação entre os parâmetros monocíclicos}

A herdabilidade encontrada indica que as variáveis são passiveis de seleção, e que o controle genético pode ser oligogênico, conforme resultados da Tabela 3 .

As elevadas estimativas de herdabilidade obtidas para os caracteres FI e II são indicativos de que se pode fazer seleção já nas primeiras gerações segregantes para esses caracteres, com possibilidades de ganhos. A seleção individual intensa para um caráter de alta herdabilidade deve também ser vista com cautela, pois esta prática poderá provocar eliminação ou perda precoce de alelos responsáveis por outros caracteres.

Verificou-se neste estudo, que a avaliação qualitativa (resistente ou suscetível) realizada no campo através da escala de severidade da doença (GI) foi compatível com os parâmetros avaliados em ambiente controlado, permitindo selecionar no campo indivíduos com alelos favoráveis para resistência a ferrugem.

As correlações entre os parâmetros monocíclicos apresentados na tabela 4 foram significativas, indicando que a ação de uma variável afeta o comportamento da outra, positiva ou negativamente. Deste modo, o grau de severidade da ferrugem (GI), observado em campo, será maior quanto maior for FI e II que por sua vez, serão menores, quanto maior for PI e PL.

Os indivíduos mais promissores a apresentarem resistência à ferrugem seriam, portanto, aqueles com maiores valores de PI e PL e menores valores de FI e II. Não necessariamente, seriam classificados somente indivíduos nível 0 na escala de severidade da doença, mas também indivíduos nível I que apresentaram tais características. Conseqüentemente, os indivíduos com os melhores níveis de resistência foram aqueles que apresentaram a melhor combinação entre os componentes de resistência, (PI, PL, FI e II) assim como é relatado para ferrugem do feijoeiro (Phaseolus vulgaris L.) e para a ferrugem da folha em aveia (Avena sativa) por Chaves, et al, (2004) (6). Nos dois casos, a resistência parcial à ferrugem não é condicionada apenas por um componente de resistência, mas sim pelo efeito conjunto de todos eles.

O predomínio de indivíduos suscetíveis indicou possíveis distorções de segregação nos cruzamentos, de acordo com hipóteses de estudos anteriores. O complemento com estudo genômico é fundamental para averiguar a possibilidade de que o gene de resistência presente nesta população dependa de outros genes que também podem segregar nos cruzamentos com parentais suscetíveis.

O presente estudo permitiu verificar que: a)O uso da escala de severidade da ferrugem no campo contribui na seleção de alelos favoráveis para resistência; b)O período de incubação e o período de latência são parâmetros monocíclicos que possuem correlação inversa com a freqüência e a intensidade de infecção, conseqüentemente, quanto maior a somatória de PI e PL menor será o potencial de severidade da doença; c)A herdabilidade elevada indica que as variáveis PI, PL, FI e
II são passíveis de seleção e que o controle genético da ferrugem pode ser oligogênico; d)A fórmula $\sum \mathrm{R}=(\mathrm{PI}+\mathrm{PL})-(\mathrm{FI}+\mathrm{II})$ é uma das maneiras de ranquear clones de acordo com o potencial de resistência para constituir um programa de melhoramento genético de eucalipto.

\section{AGRADECIMENTOS}

Os autores agradecem ao apoio recebido da Votoranim Celulose e Papel (VCP), nas pessoas Do Dr. Cesar Augusto Bonine e Dr. Donizete Dias Costa.

\section{REFERENCIAS}

1. ALFENAS, A.C., ZAUZA, E.A.V., MAFIA, R.G., ASSIS, T.F. Clonagem e doenças do eucalipto, Viçosa, UFV, 2004. 442p.

2. ALVES, A. A. Herança e mapeamento genético da resistência a ferrugem (Puccinia psidii) em cruzamentos interespecíficos de Eucalyptus. Dissertação de Mestrado. Universidade Federal de Viçosa. 2008.

3. ASSOCIAÇÃO BRASILEIRA DE CELULOSE E PAPEL. BRACELPA. estatísticas, 2013. Disponível em: $<$ www.bracelpa.org.br>. Acesso em: 2013.

4. CARVALHO, A.O., ALFENAS, A.C., MAFFIA, L.A. \& CARMO, M.G.F. Resistência de espécies, progênies e procedências de Eucalyptus à ferrugem, causada por Puccinia psidii Winter. Pesquisa Agropecuária Brasileira, 33:139-147. 1998.

5. CASTRO, H.A., KRUGNER, T.L. \& BERGAMIN FILHO, A. Especialização fisiológica no sistema Eucalyptus grandis - Puccinia psidii Winter. Ciência e Prática. Lavras 9:80-92. 1985.

6. CHAVES, M.S., MARTINELLI, J.A. \& FEDERIZZI, L.C. Resistência quantitativa à ferrugem da folha em genótipos de aveia branca: III - Correlação de Componentes de Resistência entre si e com a Intensidade de Doença no Campo. Fitopatologia Brasileira 29(2)- Mar - Abr, 2004.

7. DIANESE, J. C.; HARIDASAN, N.; MORAES, T. S. A. Screening Eucalyptus for rust resistance in Bahia. Tropical Pest Management, 32:292-295. 1986.

8. DIANESE, J. C.; MORAES, T. S. A.; SILVA, A. R. Response of Eucalyptus to field infection by Puccinia psidii. Plant Disease, 68:314-316. 1984.

9. FALCONER, D. S. Introduction to quantitative genetics. 3rd ed. New York: Longman Scientific and Technical, 1989. 438 p.

10. FERREIRA, F.A., SILVA, A.R. Comportamento de procedência de Eucalyptus grandis e de Eucalyptus saligna à ferrugem (Puccinia psidii). Fitopatologia Brasileira, v.7, p.23-8, 1982.

11. FERREIRA, F.A. Doenças bióticas do eucalipto. In: Ferreira, F.A. Patologia Florestal:Principais doenças florestais no Brasil. Viçosa-MG:SIF, p.93-233, 1989.

12. FERREIRA, M.E. \& GRATTAPAGLIA, D. Introdução ao uso de marcadores moleculares em análises genéticas. Brasília. EMBRAPA-CENARGEN. 1998. 220p.

13. FERREIRA, M. A. J. da F. Utilização das técnicas de marcadores moleculares na genética de populações, na genética quantitativa e no melhoramento de plantas. Boa Vista: Embrapa Roraima, 2003. 63p. (Embrapa Roraima Documentos, 1).

14. FURTADO, G.Q., CASTRO, H.A., POZZA, E.A. Variabilidade fisiológica de Puccinia psidii WINTER em Eucalyptus grandis e no híbrido urograndis. Summa Phytopathologica, v.31, p.227, 2005. 
15. FURTADO, E. L. ; APARECIDO, C. C. ; FIGUEIREDO, M. B. . Efeito da idade e da temperatura na germinação de urediniosporos de Puccinia psidii coletados de jambeiro (Syzygium jambos) e de goiabeira (Psidium guajava).. Summa Phytopathologica, Botucatu, v. 29, n. 1, p. 30-33, 2003.

16. GRATTAPAGLIA, D. ; KIRST, M. . Eucalyptus applied genomics: from gene sequences to breeding tools. New Phytologist, v. 179, p. 911-929, 2008.

17. HABTU, A. \& ZADOKS, J.C. Components of partial resistance in Phaseolus beans against an Ethiopian isolate of bean rust. Euphytica 83:95-102. 1995.

18. JUNGHANS, D. T. ; ALFENAS, A. C.; BROMMONSCHENKEL, S. H. ; ODA, S. ; MELLO, E. J. ; GRATTAPAGLIA, D. Resistance to rust (Puccinia psidii Winter) in Eucalyptus: mode of inheritance and mapping of a major gene with RAPD markers. Theoretical and Applied Genetics, Alemanha, v. 108, p. 175-180, 2003.

19. PASCHOLATI, S.F.; LEITE, B. Hospedeiro: mecanismos de resistência. In: BERGAMIN FILHO, A.; KIMATI, H.; AMORIN, L. (Ed.). Manual de Fitopatologia: princípios e conceitos. 3. ed. São Paulo: Agronômica Ceres, 1995. v.1, cap. 22, p. 417-453.

20. PASSADOR, G. C. Resistência à ferrugem e análise de isoenzimas em procedências e progênies de Eucalyptus. 1994. (Dissertação de mestrado) - Universidade Federal de Viçosa. Viçosa, UFV. 1994. 69p.

21. PARLEVLIET, J.E. Components of resistence that reduce the rate of epidemic development. Annual Review of Phytopathology, 1979. 17: 203-222.

22. PARLEVLIET, J.E. Resistence of the nonrace-specific type. In: Bushnell, W.R. \& Roelfs, A. P. The cereal rusts vol II: Diseases, distribuition, epidemiology and control. New York Academic Press. 1985. pp. 501-525.

23. PARLEVLIET, J.E. Strategies for the utilization of partial resistence for the control of cereal rusts. In: Simmonds, N.W. \& Rajaram, S. breeding strategies for resistence to the rusts of wheat. México, 1988. pp. 48-62.

24. PATERNIANI, M. E. A. G. Z.; DUDIENAS, C.; SAWAZAKI, E.; LÜDERS, R. R. Variabilidade genética de híbridos triplos de milho para resistência à ferrugem tropical. Revista Brasileira de Milho e Sorgo, v.1, n.1, p.6369, 2002.

25. RESENDE, M.L.V.; NOJOSA, G.B.A.; CAVALCANTI, L.S.; AGUILAR, M.A.G.; SILVA, L.H.C.P.; PEREZ, J.O.; ANDRADE, G.C.G.; CARVALHO, G.A.; CASTRO, R.M. Induction of resistance in cocoa against Crinipellis perniciosa and Verticillium dahliae by acibenzolar-S-methyl
(ASM). Plant Pathology, v.51, p.621-628, 2002.

26. RESENDE, M. D. V. Selegen-Reml/Blup. 2002.

27. ROSADO, T. B. Mapeamento de gene letal, responsável pela distorção de segregação e detecção de QTL para resistência a ferrugem (Puccinia psidii) em Eucalyptus spp. Tese de Doutorado. Universidade Federal de Viçosa. 2007.

28. RUIZ, R.A.R., ALFENAS, A.C., MAFFIA, L.A., BARBOSA, M.M. Progresso da ferrugem do eucalipto, causada por Puccinia psidii, em condições de campo. Fitopatologia Brasileira, v.14, p.73-81, 1989.

29. TAKAHASHI, S.S., CAMARGO, F.R.A., FURTADO, E.L. Avaliação de danos da ferrugem do eucalipto. In: Seminário de ferrugem do eucalipto, 1, 2000. 12p.

30. TEIXEIRA, J. E. C. Análise da herança da resistência a Puccinia psidii Winter em progênies de híbridos inter-específicos de eucalipto e mapeamento genético de um loco de resistência à ferrugem. Tese apresentada para obtenção de título de Doutor em Agronomia. Área de concentração: Genética e Melhoramento de Plantas. - Escola Superior de Agricultura “Luiz de Queiroz”, Esalq-USP. Piracicaba, 2009.

31. VIEIRA, E. A.; CARVALHO, F. I. F.; CHAVES, M. S.; OLIVEIRA, A. C.; SILVA, J. A. G.; BERTAN, I.; SCHMIDT, D. A. M.; RIBEIRO, G.; FINATTO,T.; SILVEIRA, G. Herança da resistência à ferrugem da folha da aveia (Puccinia coronata f. sp. Avenae Fraser \& Led.) em genótipos brasileiros de aveia branca. Ciência Rural, Santa Maria, v.36, n.1, p.135141, jan-fev, 2006.

32. ZAMPOGNO, K. C.; FURTADO, E. L.; MARINO, C. L.; BONINE, C. A. V.; DIAS, D. C. Utilização de análise de segregantes agrupados na identificação de marcadores ligados a genes que controlam a resistência à ferrugem (P. psidii Winter) em Eucalyptus sp.. Summa Phytopathologica, v. 34(3), p. 253-255, 2008

33. ZAMPROGNO, K. C. Utilização de bulked segregant analysis na identificação de marcadores ligados a genes que controlam a resistência à ferrugem (Puccinia psidii WINTER) em Eucalyptus sp. Dissertação de mestrado. Universidade Estadual Paulista, Botucatu. 2005. 